\title{
Victimhood, Health Challenges and Violent Restiveness in Blood and Oil: Music, Characterization and Colours as Metaphors
}

\author{
Uche-Chinemere Nwaozuzu', Adebowale O. Adeogun², Cindy Ezeugwu³,
} Alphonsus C. Ugwu ${ }^{4} \&$ Emeka Aniago 5

${ }^{1}$ Associate Professor, Theatre \& Film Studies, University of Nigeria, Nsukka, Nigeria

${ }^{2}$ Senior Lecturer, Music, University of Nigeria, Nsukka, Nigeria

3 Lecturer, Theatre \& Film Studies, University of Nigeria, Nsukka, Nigeria

${ }^{4}$ Lecturer, Mass Communication, University of Nigeria, Nsukka, Nigeria

5 Senior Lecturer, Theatre E Film Studies, University of Nigeria, Nsukka, Nigeria

emeka.aniago@unn.edu.ng ORCIDiD: oooo-ooo3-3194-1463

\begin{abstract}
This study examines the aesthetics, efficacy, and propriety of the embedded metaphors in characterization, music, and colour application as creative vision in projecting victimhood atmosphere around traumatized Niger-Deltans due to many years of deprivation in Blood and Oil. Thus, this study explains how Blood and Oil represents a credible narrative, subsuming polemics of environmental degradation, health misery, massive unemployment, subjugation, and violent restiveness in Niger Delta due to poor political leadership, greed, and corruption. On creative vision, we are discussing how the ingenious application of characterization, music, and colour combined effectively in creating an enduring mood for the scenes in the film as channels of accentuating intended messages. To add relevant scholarly rigor, we applied victimhood theory and interpretive discuss approach to create relevant and lucid insights regarding the inclinations and actions of select characters in the film as well as analysis of relevant secondary texts. In the end, we deduce that the apt portrayal of Niger-Delta oil communities' extensively degraded and polluted environment validates the reality of anguish and victimhood because of the massively diminished fishing and farming prospects. Lastly, the implication of this scenario is increased unemployment, psychological distress, diseases, and violent restiveness which have reduced enormously the wellbeing of Niger Delta inhabitants.
\end{abstract}

Keywords: crude oil, health concerns, Niger-Delta, Nollywood, restiveness, victimhood

It is probably universal that in every serious, harsh and violent intergroup conflict, at least one side - and very often both sides - believe that they are the victim in that conflict. [BarTal et al 2009: 231]

\section{Introduction}

Our study revolves around discourses offering plausible insights on interpretations of filmic portrayal of illness, poor wellbeing, and aggressive restiveness in Niger-Delta oil host communities, generated by horrendous impacts of non-eco-friendly oil exploration practices, abysmal cooperate

(c) AesthetixMS 2021. This Open Access article is published under a Creative Commons Attribution Non-Commercial 4.0 International License (http://creativecommons.org/licenses/by-nc/4.o/), which permits non-commercial re-use, distribution, and reproduction in any medium, provided the original work is properly cited. For citation use the DOI. For commercial re-use, please contact editor@rupkatha.com. 
social responsibly, and lukewarm response to complaints by government. Thus, our interpretation is premised on conceptualization of victimhood by Daniel Bar-Tal et al who explain that "there are many kinds of situations that can bring a person as an individual or as a member of a collective to have a sense of being a victim" and "that victimhood describes some lasting psychological state of mind that involves beliefs, attitudes, emotions and behavioural tendencies" (2009: 231). Therefore, in this paper, we are looking at how a Nollywood film Blood and Oil presents collective and individual sense of victimhood, which are blamed on perennial agonizing experiences of oil exploration in Niger-Delta by the host communities. Scholarly contributions providing deep and dense suppositions from several thematic trajectories and methodological approaches about realities of oil explorations in Niger-Delta and the feelings of the host communities abound. For instance, contributions by Nwaozuzu et al 2020, Ekpo et al 2018, Clark 2016, Raji \& Abejide 2013, Agbiboa \& Maiangwa 2012, Adelana et al 2011, Akpan \& Akpabio 2003, variously add emerging information as well as validate previous reports on appalling environmental degradation, government neglect, calculated suppression and the resulting health and wellbeing implications. In these works, environmental degradation is pointedly blamed for the perennial catastrophic destruction of age-long subsistence means of livelihood - farming and fishing - in most oil exploration host communities. In addition, the supposedly calculated neglect by government is seen as the major factor behind the alarming debilitating health conditions and problems, whereas the systemic suppression is blamed for the youth's violent restiveness and bloodletting.

However, studies directly devoted towards clear interpretation of filmic contributions to the portrayals of how oil exploration in Niger-Delta represents profit and monumental wealth for a few (the multinationals, corrupt government officials and their proxies) and massive economic and health misery for the host communities are scare. Regardless of the fact that, "film as a medium, possesses the propensity to unleash both aggressive and subtle efficacious propelling force on the viewers in varying proportions" and "such efficacy can invigorate or re-invigorate the consciousness, and re-engineer the viewers' worldviews and ideologies" (Aniago et al., 2020: 2). Furthermore, the importance of filmic music and characterization as complimentary narrative tools, which separately possess immense propensity to elevate the overall creative vision in a film, receives very little scholarly attention in Nollywood studies. Hence, this study intends to grow scholarly interest in this direction.

In line with the purview of this paper, creative vision for a film director is the creative deployment of functional sublime sophistication and artistry in film script interpretation to come up with techniques and approaches for characterization, acting, filming, costuming, make-up, editing, application of music and sounds, in a bid to elevate greatly the aesthetics and utility. Thus the way and manner these filmic elements are brought together in the process of making a film, define a director's creative vision concept and context. Hence, this paper examines critically the creative vision in the application of filmic music and characterisation as aesthetic devices in projecting metaphors of victimhood, the nuances of agony and aggressive restiveness in Blood and Oil. Furthermore, this study explains the metaphor of victimhood claims by Niger-Delta people as subsumed in some of the characters' utterances, which portray their inclinations, worldviews and perspectives. In line with the nature of this study, we are adopting content and interpretive research approaches for data gathering and analysis, which involve long hours of repeated screening of the case study Blood and Oil, analysis of relevant sections and aspects of the case study, and creative application of relevant scholarly contributions for purposes of enhancing our interpretations. Meanwhile, to clearly place the conceptual suppositions guiding our interpretations, we shall start with review of relevant literature. 


\section{Review of Relevant Literature and Theoretical Purview}

There are articulate studies, illuminating on the dimensions and contexts of filmic production of scenic atmospheres through music and colours embedded deliberately to encapsulate and project specific messages to the viewers. Some of these studies variously suggest that when colours and music are creatively applied in composing scenic environments and in generating specific atmospheres respectively in film-making, they enrich its aesthetics. Thus, music and colours in many ways act as complimentary narrative tools that elevate and define characters' dialogue and actions, which can help to generate efficacious consciousness and mood aggregation in the viewers. In affirmation of the above supposition, Anita Cloete observes that film "is regarded as an art that is pervasive and powerful" (2017: 1). This is because films' efficacy to a large extent revolves around the fact that it is "a cultural product and medium" which acts as "an important medium for meaning-making" (2017: 1). Our view on Cloete's contribution is that her idea essentially revolves around the understanding that as individuals view films, they are consistently presented with longlasting glimpses of other people's embedded ways-of-life, history, philosophy, environment, worldview(s) and their other social realities. Thus, the widely accepted scholarly view is that seeing films will in many ways help viewers to deepen their understanding of several subject matters about people and their societies which are subsumed in the films (see Cloete 2017; Aniago et al 2020). Therefore, the "film medium in many ways is like the literary arts in its mechanics and dynamics of entertaining, embedding, consolidating, and re-aligning of both culture-specific and universal ideas in the consumers" (Aniago et al 2020: 1). This efficacious essence alluded by Aniago et al can be achieved when there is a structural coherence which works towards creating understanding and proper consciousness to the extent that the intended messages will not remain ambiguous at the end of the story. We believe that achieving structural coherence is a clear display of filmic creative vision attained by exhibiting a well articulated overall aesthetic and didactic consistency, coupled with advanced propriety and creative judgement in plot, dialogue, action, tempo, mood intensity, and characterization sequencing and variation.

\section{Relevant Perspectives on Functionality and Efficacy of Music in Films}

Looking at music as a tool for conveying messages generally, we observe that a very good number of studies suggest that music has been in existence since the early days of mankind, that it plays vital and different roles in people's lives all over the world and that it is viewed as one of the oldest forms of expression (see Menuhin \& Davis 1979, Cross 2003; Dissanayake 2006, 2008). Also, there are plausible explanations in several reliable studies indicating that the use of music goes beyond mere consumption for leisure. These studies indicate that there are scholarly records detailing on several applications and utilizations of music for very many purposes in social, communal, and private events and ceremonies. Also music have remained consistently vital in formal and informal education, healing and health therapy, including behavioural, psychological, physiological, emotional and cognitive related utilization all over the world (see Cross 2003; Huron 2003; Aldridge 2004; Cassidy \& Macdonald 2007; Saarikallio 2010). More so, a good number of studies espouse on the efficacious complimentary roles of background music in human daily activities, and how background music are utilized in appealing to people for different purposes in advertising, retail, celebrations and education (see Sloboda et al 2001; Juslin \& Laukka 2004; Garlin \& Owen 2005 \& 2006; Zander 2006). In addition, some studies have lucidly demonstrated that music can act as an emotional stimulus; hence, in many ways, it can successfully influence an individual's concentration, articulation, perception, emotion, choice-making, and mood intensity (see Sloboda \& O'Neill 2001; Juslin \& Laukka 2004; Jolij \& Meurs 2011; Zadra \& Clore 2011). Furthermore, 
background music can help to calm nerves, reduce tension and stress, while people are waiting in long queues or on-hold phone calls (see Hui et al 1997; North et al 1997; Koelsch \& Siebel 2005; Oakes \& North 2008).

Another sphere of human endeavour that benefits immensely from music utilization is filmmaking. Existing studies demonstrate that music can influence viewer's emotion reconstitution and aggregation, which in turn propel re-aggregation of consciousness (see Boltz et al 1991; Bolivar et al 1994; Cohen 1999; Boltz 2001). To this extent, film theorists have long acknowledged that music play an important role in film, such as its contribution towards enhancing the definition of a film's story meaning, implications, and suggestions of impending actions and circumstances. We indentified in some scholarly contributions, plausible categorization of functions of music in films. These functions are, masking of interfering and unwanted sound and noises, establishing of transition, commencement, pause and end of a sequence (see Magliano et al 1996); assisting in integrating each scene's actions into one cohesive framework by creating ambiance, rhythms, emotion, and forecasting that directs the path of perception and interest (see Boltz 2004); aiding the awakening and propelling of attention to specific aspects of actions in the unfolding sequence (see Marshall \& Cohen 1988; Bolivar et al 1994); propelling alteration of mood intensity and feeling in viewers (see Pignatiello et al 1986); assisting in conveying supposed emotional inclination of characters, which enhances viewers' definition of scene and characters' mood intensities (see Kalinak 1992; Cohen 1993); it can be applied as cue or alert notification, aimed at suggesting impending situation, circumstance or action as well as propelling of transitions of actions, situations and circumstances (see Cassidy \& MacDonald 2007); it can be use for palpable calibration of action intensity as well as indication of action that is unravelling or the one about to unravel (see Cassidy \& MacDonald 2007); it can be used to express tempo and intensity, suggest, situate or define locale, specific culture, era and time of action and location. Some prominent scholars are of the view that music when applied properly can generate the right emotions for each scene, can effectively aid in decoding the characters' emotions, creation of aesthetic allure and act as purveyor of varied messages to the viewers (see Cohen 2001; Eldar et al, 2007; Tan et al 2007; Hoeckner et al 2011; Hanser \& Mark 2013).

\section{Relevant Conceptual Perspectives on Victimhood}

A close reading of what scholars have contributed in attempts aimed at deepening and broadening our knowledge on realities, dimensions and contexts of victimhood show expansive multidisciplinary scholarly efforts. In our research, we find the work of Gaelle Brotto et al (2017) a comprehensive documentation of scholarly contributions by several major scholars on various multidisciplinary approaches providing illuminating analysis and interpretation on the definition, conceptualization and contextualization of the terms victim, victimhood and victimology. Scholars such as Benjamin Mendelsohn, Hans von Hentig, Stephen Schafer, and Marvin Wolfgang are recognized for their pacesetting contributions aiding the expansion of paradigms on victimology since the middle of the 2oth century (see Ferguson \& Turvey 2009; Doerner \& Lab 2011). Our findings indicate that scholars severally adopt multidisciplinary approaches in contextualization and conceptualization of their suppositions on victimhood along different academic fields such as social psychology, law and jurisprudence, sociology, religion, politics, history, clinical psychology and conflict studies. In areas of social and clinical psychology, scholars attempt to illuminate more on reasons behind the emergence, evolution and manifestations of victimhood consciousness, ways of propelling forgiveness, restoration of trust, and reconciliation in individuals and societies that are bedevilled by conflicts at varying intensities (see Greenaway et al 2011; Abele \& Wojciszke 2013; 
Cohrs et al 2015; Hameri \& Nadler 2017; Noor et al 2017). In law and jurisprudence, scholars attempt to espouse on the social construction of 'victim' and 'victimhood' designations, how the various legal systems deal with cases and claims of victimization (see Pauley 1986; Harris 1991; Erez et al 2011). In the fields of sociology, politics and conflict studies, scholars focus on enhancing our understanding of the politics of victimhood and victim designations, claims and manifestations, how victimhood is defined, negotiated and contested, both socially and politically (see Kearns \& Finchman 2005; Derluyn et al 2015; Jacoby 2015; Mueller-Hirth 2017). Our observation is that regardless of the academic trajectory from which a scholar attempts his/her interrogation of victimhood realities and conceptualization, the core meaning of victimhood appear similar, hence according to Claire Ferguson and Brent Turvey, victimology represents "the scientific study of victims and victimization, including the relationships between victims and offender, investigators, courts, corrections, media and social movements" (2009: 2). In the United Nations Declaration of Basic Principles of Justice for Victims of Crime and Abuse of Power (1985), 'victim' is defined as "persons who, individually or collectively, have suffered harm, including physical or mental injury, emotional suffering, economic loss or substantial impairment of their fundamental rights, through acts or omissions that do not yet constitute violations of national criminal laws but of internationally recognized norms relating to human rights" (UN: $1-3)$.

Some researchers define victimization by focusing on the experienced events, thus Karl Aquino and Kristin Byron refer to "the individual's self-perception of having been the target, either momentarily or over time, to harmful actions emanating from one or more other persons" (2002: 71). Furthering, they observe that "in the most general sense, a victim is anyone who experiences injury, loss, or misfortune as a result of some event or series of events" (Aquino and Byron 2020: 71). According to Bar-Tal et al victimhood can be "defined as a mindset shared by group members that results from a perceived intentional harm with severe consequences, inflicted on the collective by another group" (2009: 229). Espousing, they observe that "this harm is viewed as undeserved, unjust and immoral, and one that the group could not prevent" (2009: 229). The supposition by Bar-Tal et al indicates that in a situation whereby a group of people claim victimhood, there is very likely another group which they refer to as the perpetrator. However, it is the view of Bar-Tal et al that the so called perpetrator usually does not accept the label perpetrator, hence groups and "societies involved in intractable conflict believe that their goals in conflict are well-justified, perceive their own group in a very positive light, and delegitimize the rival" (2009: 230).

\section{Blood and Oil: Characterization, Music and Colours as Metaphors}

The film Blood and Oil commences with mournful scenes where corpses were being carried in a solemn procession, accompanied with melancholic music (songs) captured in snapshots 1, 2, 3, and 4 below. The snapshots present a group of villagers in procession bearing a corpse of a relative who died as a result of debilitating effects of environmental degradation emanating from non-ecofriendly process of oil exploration in their village. 


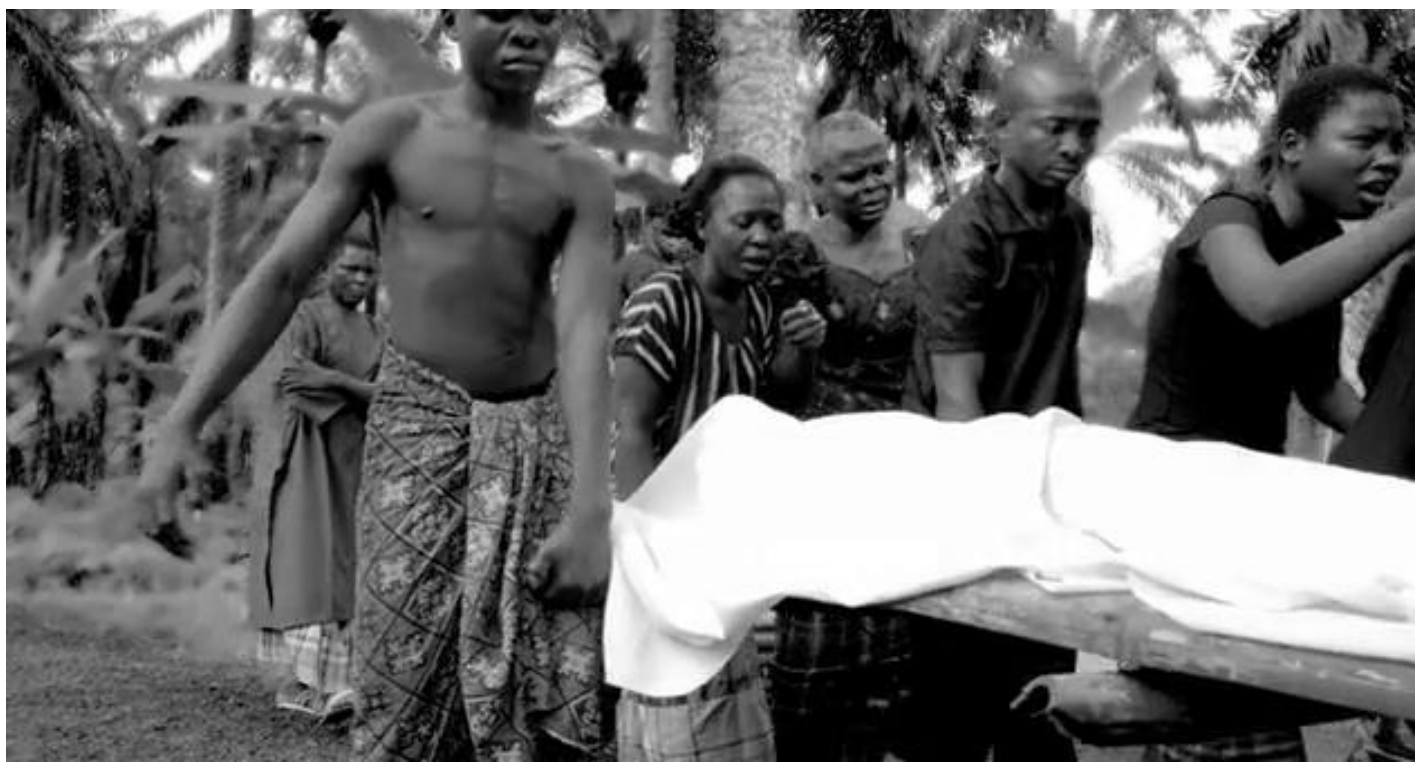

Snapshot 1 from Blood and Oil is a mourning procession by villages preparing to bury a relative who died from ill-health after drinking oil contaminated water due oil spillages.

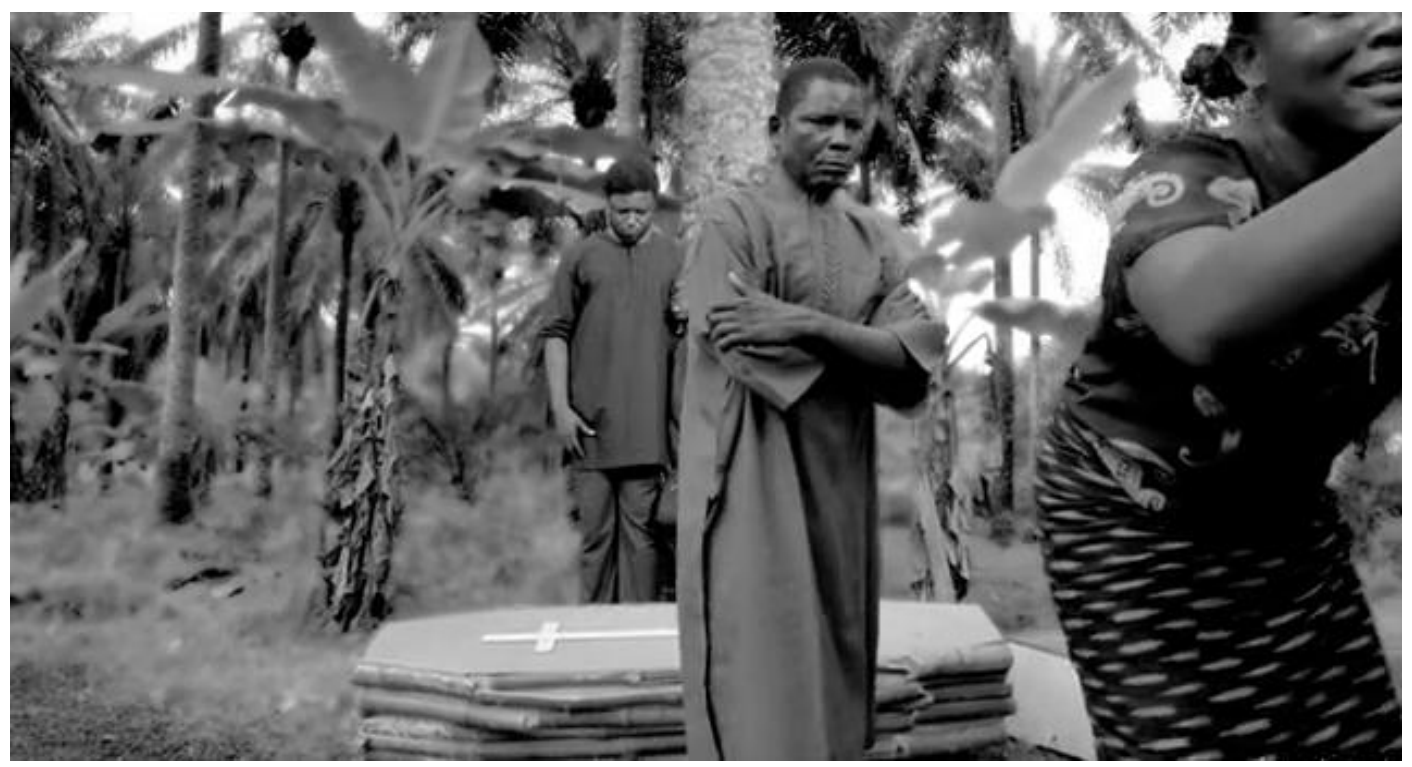

Snapshot 2 Blood and Oil shows mourners and a coffin containing a dead relative who died after drinking oil contaminated water.

\section{Colours and Sounds as Symbols and Denotations}

The colours of the cloths the villagers are wearing as captured in snapshots 1, 2, 3 and 4 project deep grief and mourning. They also compliment and accord with the mourners' facial expressions. Also the editing effect which creates an ash-dark hue inspires the atmosphere of gloom appropriate for mourning. The covering of the corpse with a white cloth which reflects the usual practice in most villages in Niger-Delta, helps to compliment and substantiate the typical reality essence of the scene narration. More so, the shape, design and colours of the coffin in snapshots 2 and 3 elevate the 
realism of the narration because they project the economic status and the usual practice of the people being depicted. Thus, the creative vision evident in the mentioned inclusions elevates propriety of the central theme of the film - victimhood. The application of close shot as captured in snapshot 3, which lingered in the film, is a filmic technique which helps to enhance emphasis. The faces of the individuals in this scene depict anguish and deep pain. The space where the mourners gathered in snapshot 1, 2, 3 and 4 for the funeral, projects evidence of environmental degradation and soil pollution as a result of oil spillages. Meanwhile, the cadence, rhythm and feeling emanating from the background music which aptly synchronizes with the sobbing and crying of the women in the solemn procession, captured in the snapshots above, produce moving emotional melancholic ambiance. The dolling of church bell, synchronized accordingly with muffled sobbing subsumes the metaphor of grief and death. The dolling bell creates a sound that is universally acknowledged, and specifically in this film, critics can use its inclusion to calculate the era the burial is located. The background music and sound (dolling of church bell) assist in conveying the supposed emotional inclination of the characters, which add to the enhancement of the viewers' definition of the scene and mood intensity (see Kalinak 1992; Cohen 1993).

The feeling created in the scenes partly captured in the snapshots are universal common, hence through the portrayal of the burials, the film sufficiently instils the required atmosphere, mood and emotion for the viewers. Then the significance of the background music which is rendered in Ijaw language with a melancholic feminine tone helps to define the locale specific ambiance of the preceding scene. This is in concordance with the postulations of Marshal and Cohen (1988), and Bolivar et al (1994) that background music aids the awakening and propelling of viewers' attention to specific aspects of the unfolding scene. As this song continues, the picture of a reddish sky-view and thick dark smoke continually moving upwards, project the intense environmental despoil and pollution (see snapshot 9).

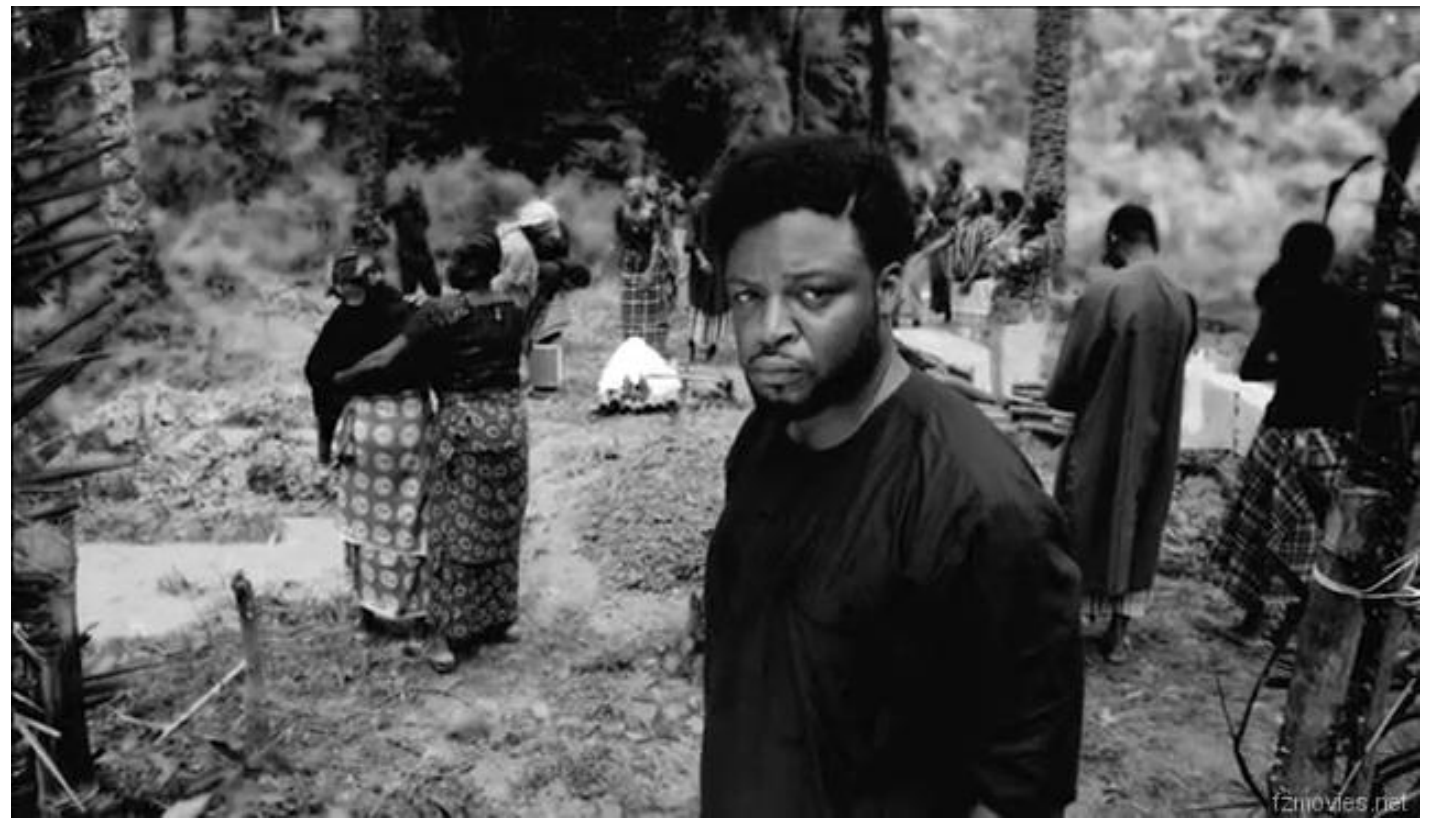

Snapshot 3 shows mourners and coffins containing dead relatives who died after period of suffering health condition resulting from oil contaminated water.

\section{Actual Images and Symbols and Metaphors}

At the beginning of the film, images such as those captured in snapshots 1, 2, 3, and 4 were applied 
to create focus on the subject of conflict in Niger-Delta, which is the litany of problems and agony because of the way and manner of oil exploration in and around the villages. The adoption of Oloibiri, the acknowledged town in current Bayelsa State where oil exploration began in Nigeria, as the locale in Blood and Oil is deliberate and telling. Snapshots 5 and 6 below, show healthy trees and river respectively in a Niger-Delta village, when the inhabitants (both humans and animals) enjoyed clean unpolluted air and (water) river as they engage in their age-long occupation of fishing and farming.

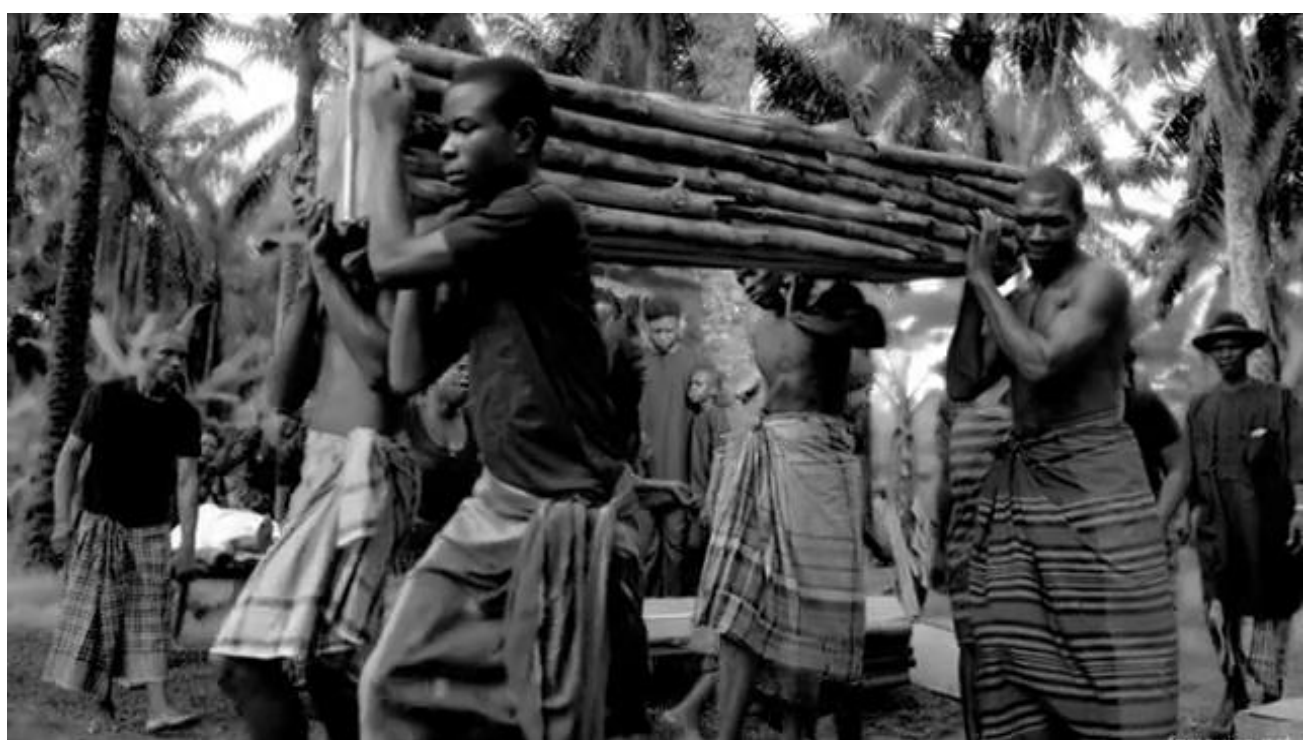

Snapshot 4 shows mourners and coffin bearers moving corpses of relatives who died after suffering health conditions because of environmental pollution.

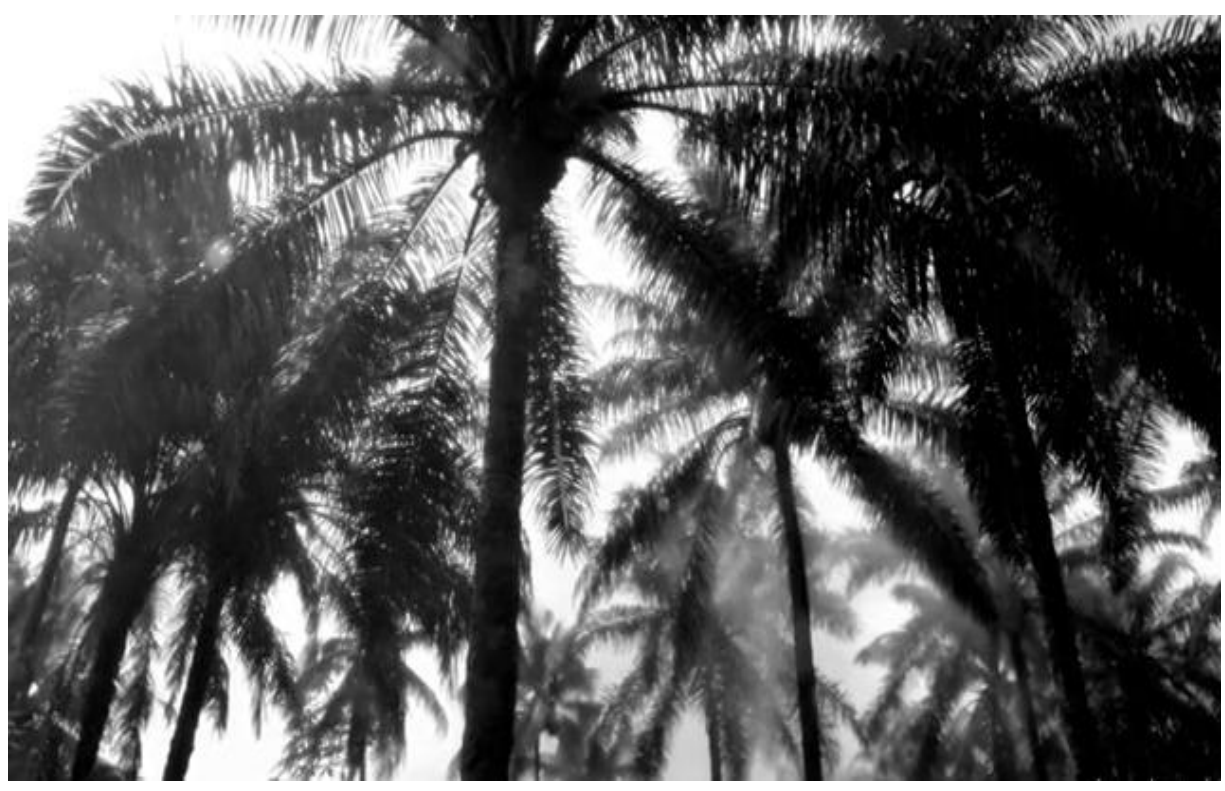

Snapshot 5 shows healthy palm trees under clear unpolluted environment before oil exploration in NigerDelta 


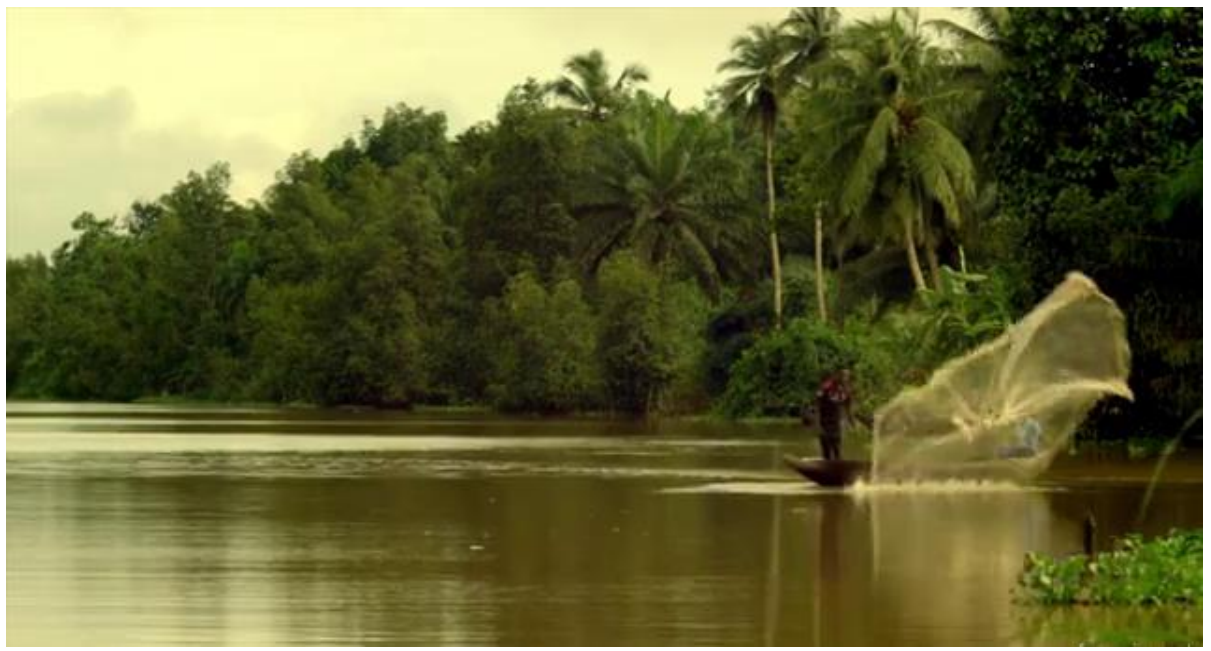

Snapshot 6 shows a fisherman attempting to fish in clear unpolutted river and environment before commencement of oil exploration in Niger-Delta

Thus, the inclusion of these frames in the film is to suggest the quality of the eco-system before the commencement of oil exploration in 1956 in Niger-Delta. Oil exploration steadily and rapidly turned the environment into a degraded and massively polluted landscape and atmosphere, because of the continual oil spillages and poisonous gas flaring, as captured in snapshots 11, 12, 13 \& 14. This environmental degradation denies the inhabitants the opportunity to fish in their waters because the fishes are being exterminated rapidly by oil spillage toxins. They could not farm because the farm lands are covered in spilled crude oil. More so, the people could not get unpolluted drinking water and are force to breathe polluted toxic air. Hence the reports of increasing cases of malignant and chronic ailments. There are also growing cases of psychological trauma and despondent feeling leading to drug abuse and crime. Therefore Blood and Oil creatively captures the enormity of problem faced by the Niger-Delta inhabitants after sixty-four years of continuous oil exploration in and around their communities, resulting in massive wealth for the Nigerian government and the multinational oil companies, who repatriate their profits to their countries for development and comfort as indicated in the scenes in snapshots 7, and 8 below, which show beautiful, healthy office and sprawling city.

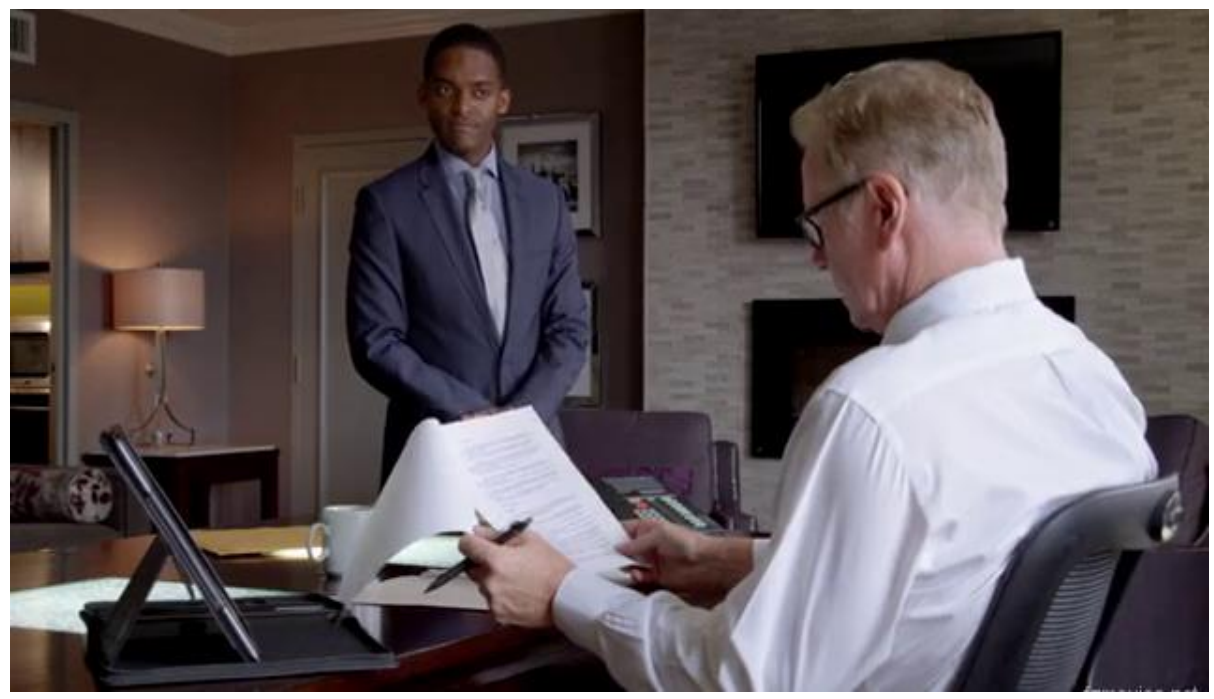

Snapshot 7 shows Robert Powell in his modern luxury offfice in America 


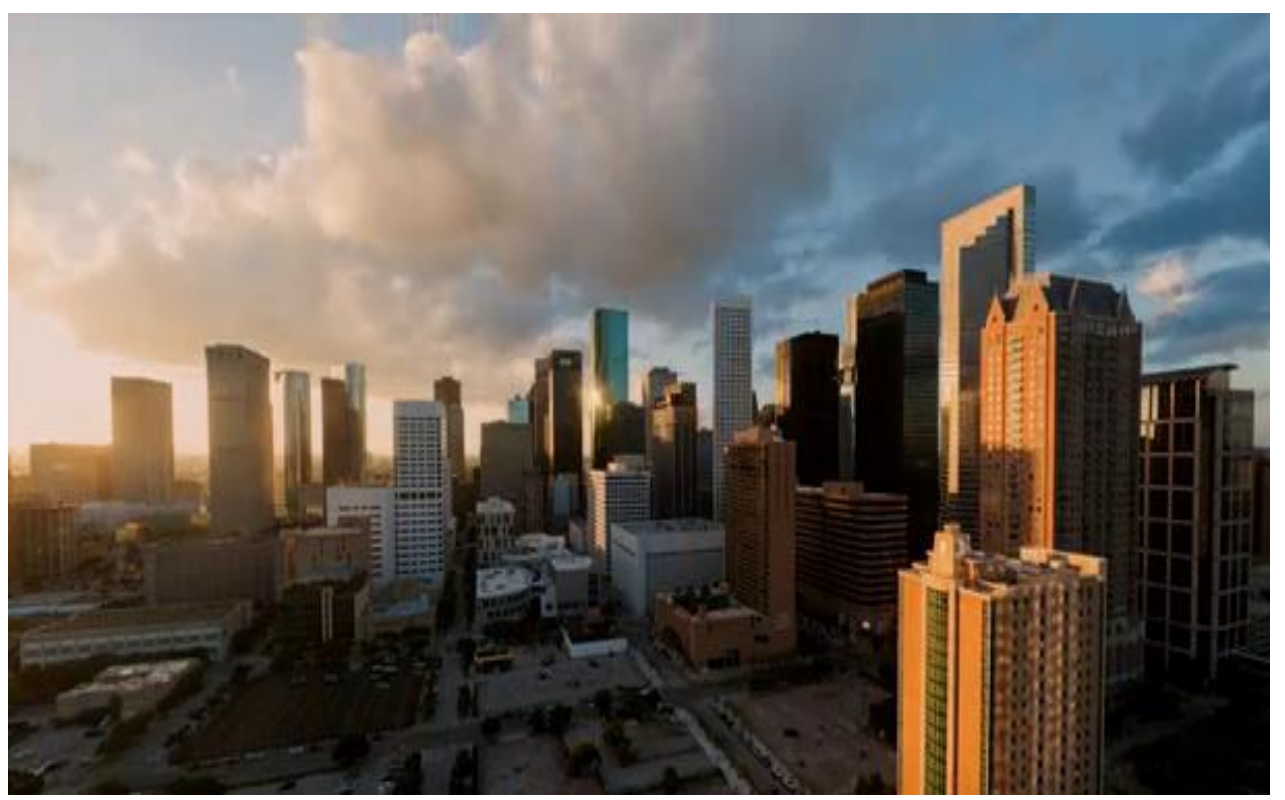

Snapshot 8 shows the city of Texas in America where Robert Powell and his resides

The snapshots 7, 8 and 9 in many ways subsume the point-of-views of the restive Niger-Delta youths, who wonder why the owners of the multinational oil companies such as Robert Powell will live in luxury and clean environment as depicted in snapshots 7 and 8 , whereas the inhabitants of oil host communities continue to dwell in such a place depicted in snapshot 9. The snapshot 9 depicts dilapidated poor houses which exist without any evidence of modernity or luxury. The snapshot 9 also show that people dwelling in such houses are staying very close to oil and gas fields where poisonous gasses are flared continually. These flared gasses are detrimental to the inhabitants' health and wellbeing. The youth thus, suggest that they are collectively victims of inhuman treatment by the federal government and the multinationals who are more interested in making profit from oil exploration. Therefore snapshot 9 is a powerful metaphorical frame which captures the disappointments and anger that pervade the host communities which subsume their sense of victimhood.

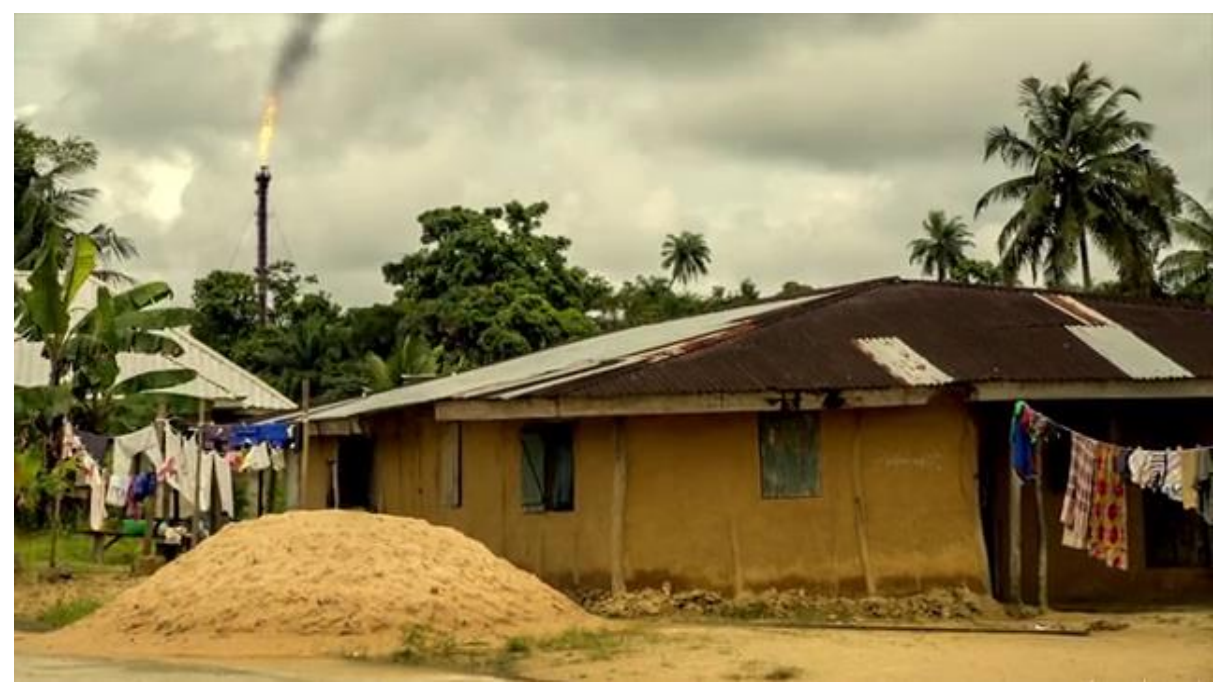

Snapshot 9 is a typical house in oil host communities in Niger-Delta in 2021 


\section{Characterizations as Metaphors and Denotations}

Casting our view at the application of characterizations in Blood and Oil as dense metaphors for purposes of projecting messages suggesting victimhood, we shall focus on six characters. They are Timipre Dobra (a grandfather, an indigene of Oloibiri, who is above seventy years old), Ebiere (Timipre's wife), Boma 'Gunpowder' (Timipre's son and a dreaded militant gang leader) and Boname (Timipre's grandson and a recent university graduate). Others are Dogo (a rival militant gang leader), and Robert Powell (Chairman of Foreshaw oil multinational). Timipre and Ebiere who were both youths in 1956 when oil exploration commenced in Oloibiri, represent the old generation, who the youth claim failed to avert the current agony the host communities are winessing because they were docile, complacent and short-sighted. They represent the generation that are less informed educationally and know next to nothing about corporate social responsibility obligations of oil multinationals. Thus, this generation did not foresee the consequences of oil exploration in Niger-Delta. Timipre who represents this generation, suffers memory loss and post traumatic stress disorder due to his subsisting psychological burden of self disappointment and anguish because he blames himself and his generation for doing less than enough to forestall the current ruin and painful reality. For instance, in his conversation with the doctor at the village clinic (in the dialogue below) he displayed anger, regret, shame and melancholy.

Timipre: Another company has commenced oil exploration in Otuabaki.

Doctor: Why worry about another village?

Timipre: Why worry? We are one people. When Lesh Petroleum destroyed Oloibiri! Oloibiri's rivers and land...

Doctor: What hurts you most in all of this?

Timipre: Oil exploration! Our nephews have turn kidnappers. If I had protested and held my ground in the 6o's, all these will not be happening. All these! I have let my community down. (After the last word, he is overwhelmed by regret and the film shows images instigating his agony and trauma)

Gunpowder and Dogo represent the radicalized militant youth generation of Niger-Delta, who are aware of the huge monetary value of oil. This generation are educated and computer savvy. They have the ability to seek and obtain help from sympathetic youths and groups all over the world. They understand the power of well articulated resistance against an oppressive government and their proxies. However, Dogo is portrayed as the metaphor of self-seeking corrupt individuals, who see the conflict as their opportunity to criminally enrich themselves. Gunpowder on the other hand is depicted as an intelligent young man who graduated with a first class degree in geology and thereafter gained employment in an oil company in Niger Delta. However, he abandons this job and joins other restive youths to start a militant group with the aim of forcing the federal government to accord the Niger-Delta people the right to resource control. Their operational method is sporadic infliction of serious economic sabotage through destruction of major oil pipes, flow stations, and other oil exploration and distribution facilities to cause disruptions. They also engage in kidnapping of oil workers, mostly expatriates as a way of instilling fear in those planning to relocate to Nigeria to work for oil multinationals as well as prompting those already in Nigeria to leave in a hurry. This is aimed at denying the oil multinationals of specialist workers in a bid to diminish the volume of their production and sales, which will consequently hurt the federal government when the projected accruable revenue is grossly reduced.

Boname who just graduated with a good Bachelor of Art degree and is waiting for his mobilization to the National Youth Service is presented as a calm and cool-headed person, focused on finding and retaining an employment. He represents the current youth generation of Niger- 
Delta who are not radicalized, thus not part of the militant gangs. However, according to the militants who have no respect for his kind, he represents the metaphor of weakness and the unfortunate continuation of docility that typified the complacent old generation.

Robert Powell is an American investor and Chairman of Foreshaw oil multinational, which recently secured licence to commence oil exploration in a Niger-Delta community near Oloibiri. He represents the 'foreign' investors who have profited immensely from oil exploration in NigerDelta since 1956, but have done very little or nothing to develop Niger-Delta which remains very underdeveloped and alarmingly polluted. Powell in a board meeting with shareholders in America declared that Foreshaw is projecting a pre-tax income of about \$300 million US dollars in the coming financial year. However, Powell who is portrayed as a good conscience person, after seeing the pictures sent through Gunpowder's proxies, (see snapshot 10 below), apparently feels the pains of the villagers and vows to do good and right.

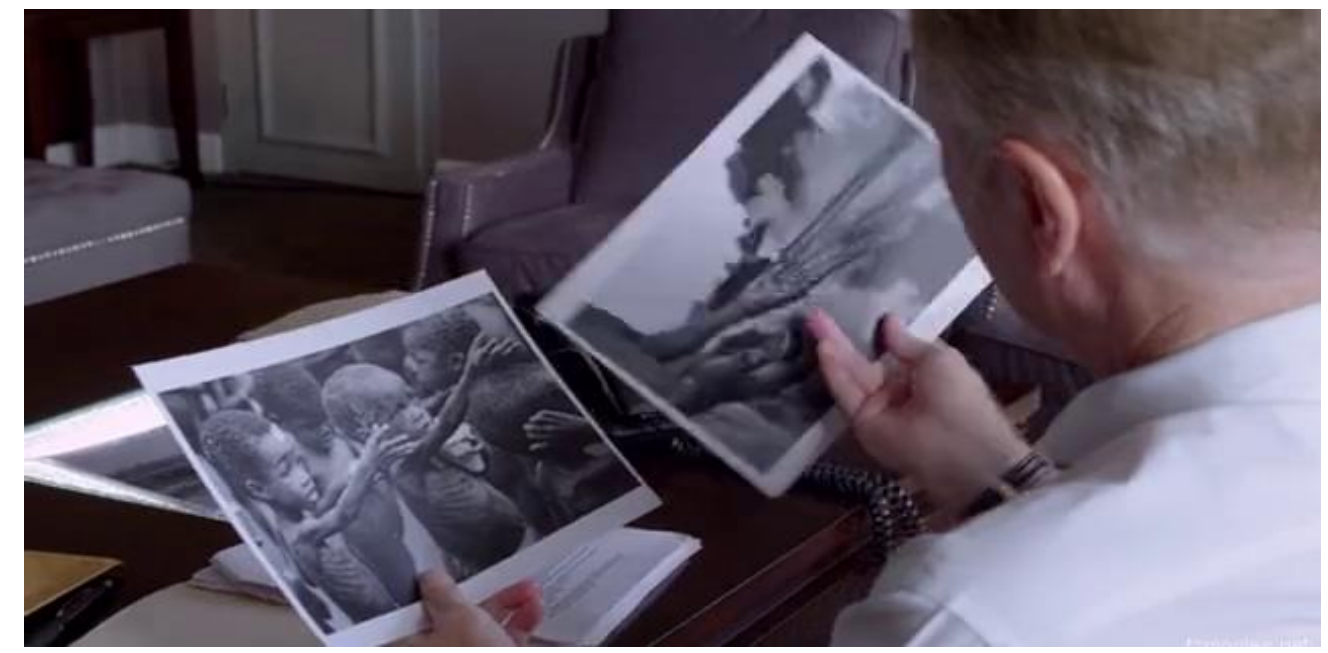

Snapshot 10 shows Powell looking at pictures of poverty stricken children in Niger-Delta oil host communities

More so, five executive members of Foreshaw received the same pictures as Powell, so in response, he summons an emergency board meeting and declares his intent to visit the host communities to see how he can assuage their pains through a robust corporate social responsibly engagement. At the meeting, he engages his Nigerian company MD in conference video call, informing him of the disturbing pictures and his intent to visit the host community. In his response, the MD flippantly notes that the issues of displeasure and anger from the host communities are among things that have been in existence for decades around oil exploration in Niger-Delta and that they have a way of taking care of it. According to the MD, to take of it they usually use proxies to find and compromise the aggrieved militant groups, elders, and government officials with money. However, Powell in his selfless and conscientious disposition discards the advice and sticks with his resolve to embark on a visit to Niger-Delta. The excerpt below relays the discussion in the emergency Board meeting.

Robert Powell: GM, are you there?

GM: Yeah!

Robert Powell: We are a little concerned on this side.

GM: What we do is find out the group that are behind this? There is nothing money cannot do. (Laughs) Ha - ha - ha - ha. 
Another Board Member I: This can interrupt setting up.

GM: Listen. Oil companies have been in the Niger-Delta for decades. You pay the needful, they keep working

Robert Powell: The photos show that these people are in profound pain.

GM: Trust me. We have to find the group that sent them, we pay them, and it will be OK.

Another Board Member II: You're right. Just like Can Oil did.

GM: Alas Petroleum too.

Robert Powell: When I founded Foreshaw, I set out to be different in Niger-Delta. That's what I want us to be, different.

With this last comment, Powell ends the meeting and insists that he will visit the host community, to see things for himself and workout ways of ensuring that they are sufficiently helped to live better and happy. However, Powell's travel schedule is relayed to Gunpowder by his assistant Mr. Azu who is an affiliate Gunpowder's militant gang. This information provided Gunpowder with opportunity to arrange promptly the kidnapping of Powell when he gets to Niger-Delta. What this scenario suggests is that Gunpowder operates with some level of sophistication because he was able to infiltrate Foreshaw Oil Company as well as kidnap Powell's wife and daughter from their home in Texas hours after Powell embarked on his journey to Nigeria. Gunpowder used the kidnapped wife and daughter as bargaining leverage to successfully compel Foreshaw Oil Company to withdraw its interest in exploring oil in Niger-Delta.

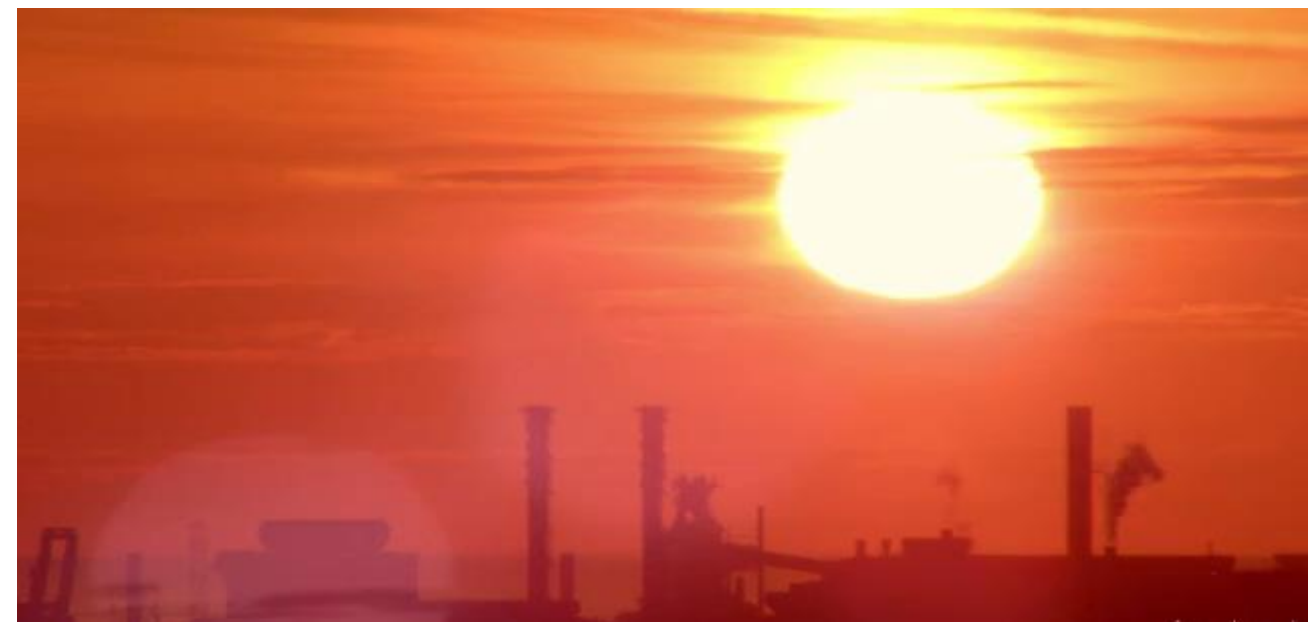

Snapshot 11 from Blood and Oil shows the atmosphere massively polluted with flayed columns of gasses and smoke from oil fields around villages in Niger-Delta host communities.

The snapshots labelled 11, 12, 13, and 14 creatively added in the frames in the beginning and other stages of the film, poignantly present tales of neglect, pain, anguish, disaster and degraded standard of living. They are strong evidences of subsisting conditions and realities six decades after billions of dollars have been earned from Niger-Delta oil sales. Thus, these are tacitly presented in this film as reasons for the upsurge in debilitating diseases and violent restiveness. In addition, by implication, these four snapshots deliver the widely acknowledged unfair treatment feeling harboured by Niger-Delta people. 


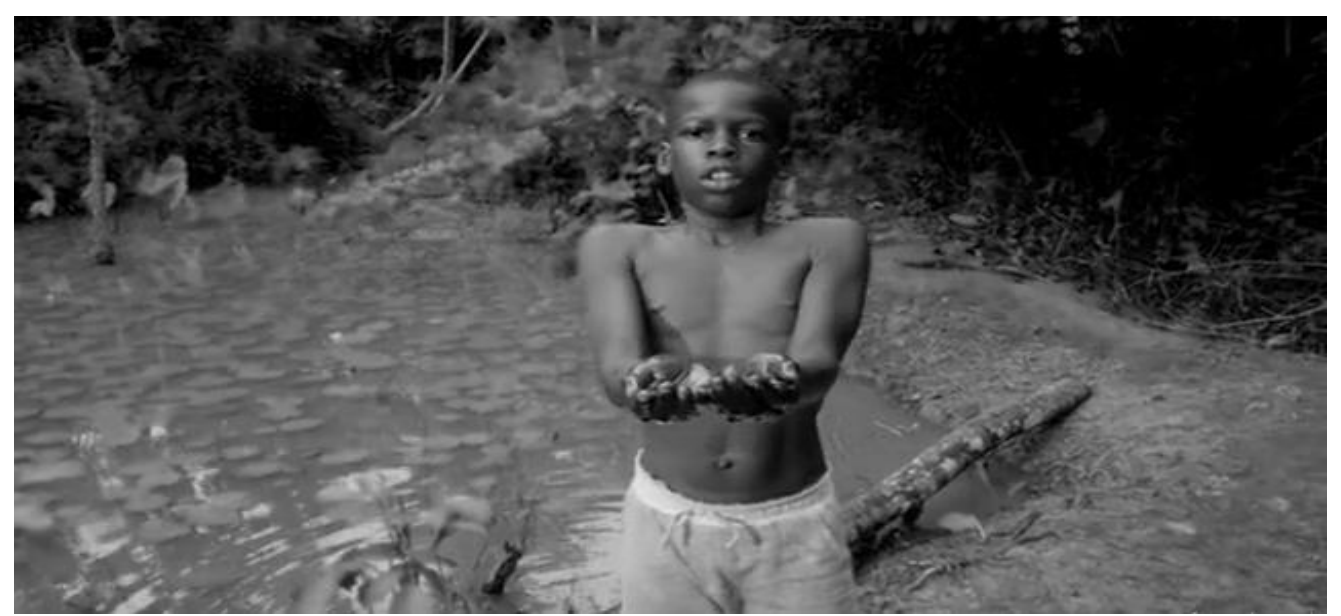

Snapshot 12 from Blood and Oil showing a boy holding water scooped from oil contaminated stream in a host community.

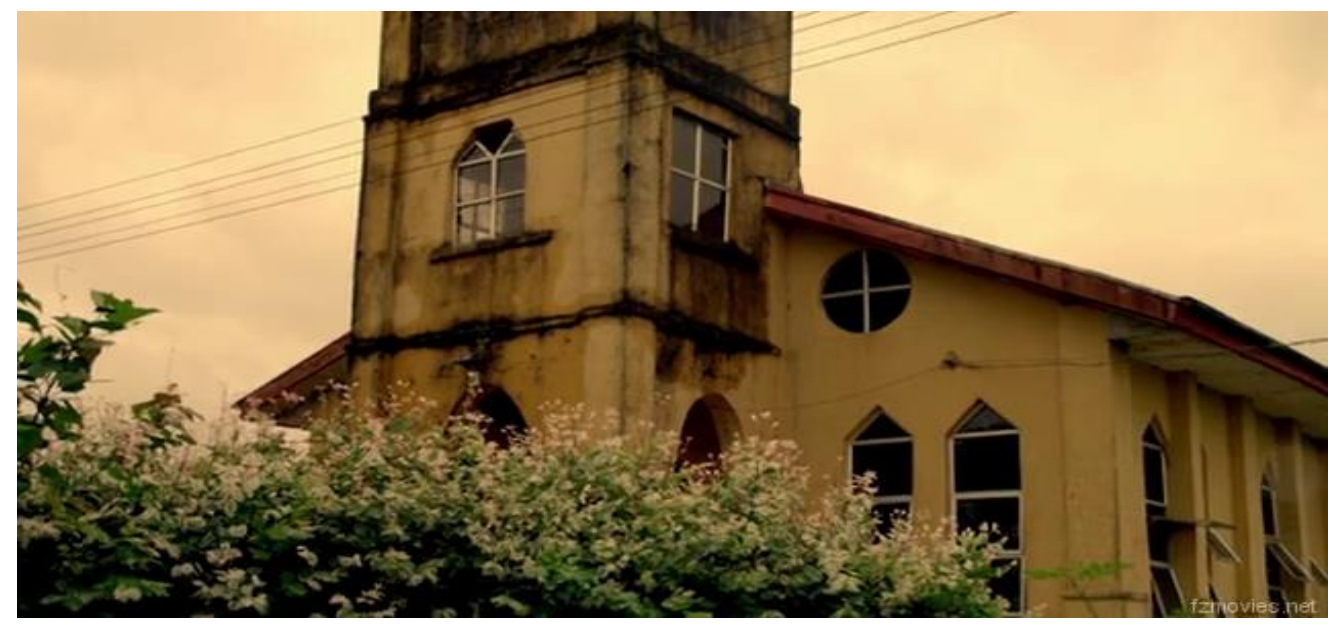

Snapshot 13 is a dilapidated and crumbling church building in the host community

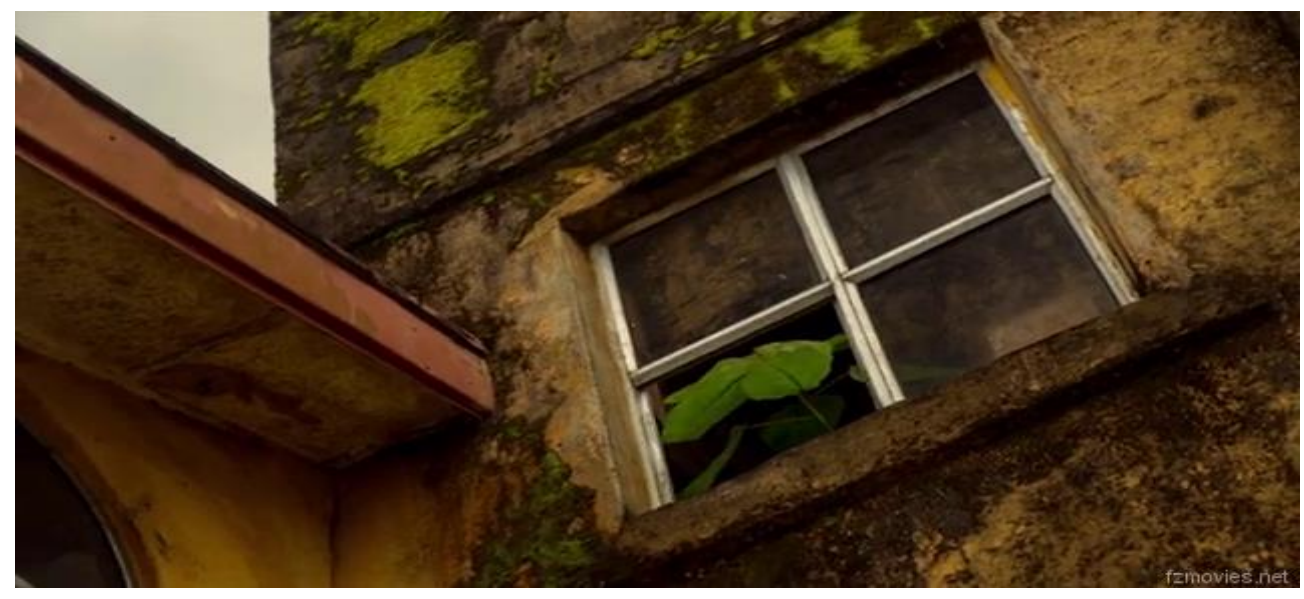

Snapshot 14 is a close shot of a section of the church building in snapshot 13 above. 


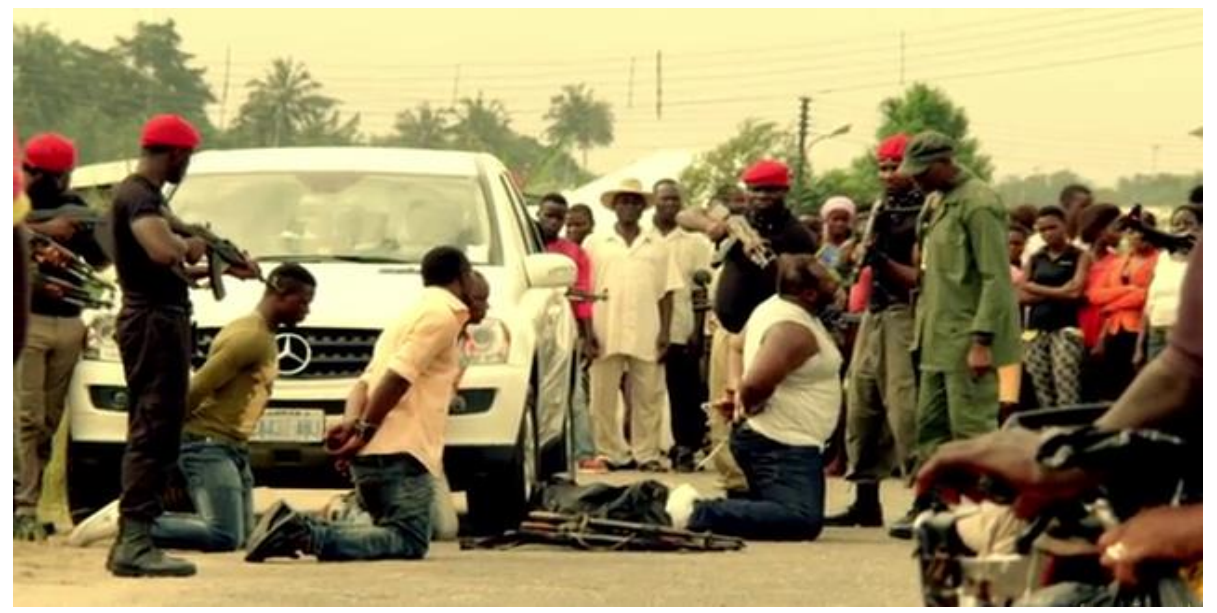

Snapshot 15 shows Gunpowder holding Dogo and his gang under gun-point in the middle of a road with onlookers surrounding them.

In the above snapshot, Gunpowder holds Dogo and his gang under gun-point. They are kneeling on the tarred road with their hands tied behind their backs while the villagers watch with palpable trepidation. The following conversation between Gunpowder and Dogo from the scene indicated in the snapshot 15 pointedly portrays nuances of greed, corruption, victimhood, and violence.

Gunpowder: Dogo! Dogo! Dogo the great! Another day, another naira eh!

Dogo: Hope you will like the anger of the beast, when I get you. My boys and I will make you a cocktail for the beast.

Gunpowder: But I got you first, eh! Let us play a game. Let us play a game called judgement day. I ask the question, you answer, and I judge.

Dogo: You will let me go. I am your friend. We started this together. Me and you, Remember.

Gunpowder: Until greed got you Dogo. We vowed to... We vowed to protect Oloibiri, you and I.

Dogo: See this money Gunpowder, have it all.

Gunpowder: Why, because you know where to get some more? Em! Do you use this money to profit Oloibiri? Do you think destroying the values of Niger-Delta solves the issues? My friend, answer me. This game is getting boring.

Dogo: We fight the same course.

Gunpowder: No Dogo, you fight for your stomach. Look at your boys. They are now common thieves like you. Dogo you are a contagious disease.

Dogo: You are not better than me. You are evil just like me.

At this moment Gunpowder ends the dialogue and shoots Dogo point blank repeatedly killing him instantly. In response, most of the villagers shriek. However, Gunpowder lets Dogo's gang members live, because he concludes that they are merely taking orders from a misguided and corrupt leader. Thus, he admonished them not to be like their self-seeking late leader. Subsequently, he instructs his boys to share Dogo's bag of cash to the onlookers, who cheer in return. Gunpowder and Dogo were formerly co-gang leaders before they broke ranks because of Dogo's apparent greed for money. The metaphor here is that it is gang leaders like Dogo, the MD of Foreshaw is referring to when he alludes to individuals they bribe, so that oil exploration will continue. Gunpowder infers that gang members like Dogo are disguising as militant freedom fighters for selfish ends, thus he justifies his 
execution of Dogo. After the incident on the road where Gunpowder killed Dogo, his mother Ebiere took the risk and pains to visit him in his creek hideout and their discussion is captured in the following dialogue.

Gunpowder: Mama!

Ebiere: Boma, next time you take another life, I will curse you. What happened to my boy? The son who made $1^{\text {st }}$ class degree in Geology and secured a good job. What happed to him?

Gunpowder: He died mama, because the elders failed. He died (crying)

After the conversation, Ebiere who appeared traumatized by her son's hard-hearted disposition and gruesome actions exits from the room in apparent agony. Just like her husband, the debilitating effect of the oil exploration gives her grief and psychological trauma, but she agonizes more over her son's militancy and bloodletting. Subsequently Gunpowder and his gang visit his mother in their village house because she is not picking his calls. The following dialogue registers their feelings and projects the melancholy that envelopes the oil host communities.

Gunpowder: Mama, I have been calling you and you're not picking.

Ebiere: I opened your letter. It's from Lesh Petroleum. For two years, a multinational oil company begs a former employee to return to a job he dumps. But he arrogantly refuses. Emmm... Who put this curse on you Boma? (She coughs violently, spitting droplets of blood)

Gunpowder: Are you still drinking from the river?

Ebiere: The poison is not only in our rivers.

Gunpowder: Mama! Please! Let me take you to the hospital.

Ebiere: The doctors already have seen me.

Gunpowder: And you want me to make money from the same company that is killing Oloibiri's children (He tore the re-appointment letter and angrily walks out on his mother, as she sobs bitterly)

\section{Contexts of Victims as Perpetrators}

The dialogue above suggests the possibility of a victim becoming a perpetrator at the same time he or she subsists as a victim. Gunpowder's mother Ebiere indicates that her son even though a victim of crimes of oil exploration in Niger-Delta, has turned to a perpetrator. This aligns with the position of Diane Enns who observes that "victims can become perpetrators, and can in turn be re-victimized yet again, or victims can be perpetrators simultaneously" (2007: 11). This view explains why Masi Noor et al attest that "collective victimhood experiences are complex, multi-layered, and are among some of the most impactful experiences that individuals and groups can have" (2017: 129). No doubt, the people of Oloibiri as portrayed in Blood and Oil are victims of bad realities of oil exploration in many ways; however, the kidnapping of innocent individuals makes the restive youth perpetrators of other criminalities. In his observation Tomaž Erzar notes that "oftentimes after violent events, opposing groups persevere in the state of victimhood and transfer the emotional burden of the conflict to younger generation" (2018: 46). This context is witness in the behaviour of Timipre, who continues to lament and circulate the epiphany of victimhood to his descendants and others. Lastly, this film Blood and Oil reaffirms the observation of Nwaozuzu et al who note that "scholarly reports, films, documentaries and creative literary inputs on Niger Delta people's perception of their livelihood in their environment in relation to oil and gas realities and experiences, are filled with tales of agony, dehumanization, brutality and gutter politics" (2020: 32).

\section{Conclusion}

Blood and Oil is an unambiguous attempt aimed at portraying poignantly the realities of oil 
exploration in communities in Niger-Delta by espousing on salient point-of-views, relevant historical and subsisting realities. Our analysis of the portrayals in Blood and Oil accords with the view that sometimes "film-makers consciously attempt to appropriate the film medium for the purpose of socio-political and/or cultural engineering or reengineering of the philosophical trajectories and perspectives of the target film consumers" (Aniago et al 2020: 2). This is because this film contextualizes plausible paradigms, applying subtle but poignant blames, attempting to attack the consciousness of both the distant and near observers. It is an actual reality filmic enactment, which avoids dislocation of facts in its attempt to project unequivocal sordid realities brought about by distasteful process of oil exploration which perpetuates people's exploitation in Niger-Delta. This film through creative combination of music, locations, and characters' utterances adds metaphors that embody victimhood inclinations of the oil exploration host communities. The choice of portrayal in many ways negates the modality of advocacy film, in which case attempt is made to project what is to be termed negativity as clearly as possible through characters who exhibit pristine positivity actions. This is not the case in this film because Gunpowder and his kind, may not appeal to many universal viewers; however, this film represents the facts. More so, this film provides moving and emotional visuals which in many ways penetrate stronger and faster than written accounts. In the end, we agree with Aniago et al that "it will not be out of place to suggest that the film-maker is in many ways a philosopher, an opinion moulder, a manipulator of emotions and a conjurer of ideas" (2020: 2), who places ideas in the public domain to instigate debates just as in Blood and Oil.

\section{References}

Adelana, S. O., Adeosun, T. A., Adesina, A. O., \& Ojuroye, M. O. (2011). Environmental pollution and remediation: challenges and management of oil spillage in the Nigerian coastal areas. American Journal of Scientific and Industrial Research, 2(6): 834-845.

Agbiboa, E. D., \& Maiangwa, B. (2012). Corruption in the underdevelopment of the Niger Delta in Nigeria. The Journal of Pan African Studies, 5(8): 108 - 132.

Akpan, N. S., \& Akpabio, E. M. (2003). Youth restiveness and violence in the Niger Delta region of Nigeria: implications and suggested solutions. International Journal of Development Issues, 2(2): 37 - 58.

Aldridge, D. (2004). An overview of music therapy research. Complementary Therapies in Medicine, (2): 204 $-126$.

Aniago, E., Okpara, C. V., \& Nwaozuzu, U. C. (2020). Metaphors of Igbo worldviews on ghosts as mystical realities: interpretations of filmic portrayals as archetypal and imaginative visual aesthetics in two Nollywood films. Rupkatha Journal on Interdisciplinary Studies in Humanities, 12(1): 1 - 13.

Aquino, K. \& Byron, K. (2002). Dominating interpersonal behaviour and perceived victimization in groups: evidence for a curvilinear relationship. Journal of Management, 28(1): 71.

Bar-Tal, D., Chernyak-Hai, L., Schori, N., \& Gundar, A. (2009). A sense of self perceived collective victimhood in intractable conflicts. International Review of the Red Cross, 91(874): 229 - 258.

Bolivar, V. J., Cohen, A. J., \& Fentress, J. C. (1994). Semantic and formal congruency in music and motion pictures: effects on the interpretation of visual action' Psychomusicology, (13): $28-59$.

Boltz, M. G. (2001). Musical soundtracks as a schematic influence on the cognitive processing of filmed events. Music Perception, (18): 427 - 454.

Boltz, M. G. (2004). The cognitive processing of film and musical soundtracks. Memory \& Cognition, (32): $1194-1205$.

Boltz, M., Schulkind, M., \& Kantra, S. (1991). Effects of background music on the remembering of filmed events. Memory \& Cognition, (19): 593 - 606. 
Brotto, G. L. M., Sinnamon, G., \& Petherick, W. (2016). Victimology and predicting victims of personal violence. The Psychology of Criminal and Antisocial Behaviour: Victim and Offender Perspectives, edited by Petherick, W. \& Sinnamon, G. London: Elsevier Science \& Technology, 79 - 144.

Cassidy, G. \& MacDonald, R. A. R. (2007). The effect of background music and background noise on the task performance of introverts and extraverts. Psychology of Music, (35): 517 - 537.

Clark, E. V. (2016). The politics of oil in Nigeria: transparency and accountability for sustainable development in the Niger Delta. American International Journal of Contemporary Research, 6(4): 76 82.

Cloete, A. L. (2017). Film as medium for meaning making: A practical theological reflection. HTS Teologiese Studies/Theological Studies, 73(4): 1 - 6.

Cohen, A. J. (1993). Associationism and musical soundtrack phenomena. Contemporary Music Review, (9): $163-178$.

Cohen, A. J. (1999). The functions of music in multimedia: A cognitive approach, In: S. W. Yi (ed), Music, mind, and science. Seoul: Seoul National University Press, $53-69$.

Cohen, A. J. (2001). Music as a source of emotion in film In P. N. Juslin \& J. A. Sloboda (Eds.), Music and Emotion. Oxford: Oxford University Press, $249-272$.

Cross, I. (2003). Music, cognition, culture, and evolution In I. Peretz \& R. J. Zatorre (Eds.), The Cognitive Neuroscience of Music. New York: Oxford University Press, $42-56$.

Derluyn, I., Vandenhole, W., Parmentier, S., \& Mels, C. (2015). Victims and/or perpetrators? Towards an interdisciplinary dialogue on child soldiers. BMC International Health and Human Rights, 15(28).

Dissanayake, E. (2006). Ritual and ritualization: Musical means of conveying and shaping emotion in humans and other animals' In S. Brown \& U. Voglsten (Eds.), Music and Manipulation: On the Social uses and Social Control of Music. Oxford: Berghahn Books, $31-56$.

Dissanayake, E. (2008). If music is the food of love, what about survival and reproductive success?' Special issue: Narrative in music and interaction Musicea Scientia, 169- 195.

Doerner, W. G., \& Lab, S. P. (2011). Victimology (6th ed.). Cincinnati: Lexis Nexis/Anderson Publ., Company

Ekpo, I. E., Obot, O. I., \& David, G. S. (2018). Impact of oil spill on living aquatic resources of the Niger Delta region: A review. Journal of Wetlands and Waste Management, 2(1): 48 - 57 .

Eldar, E., Ganor, O., Admon, R., Bleich, A. \& Hendler, T. (2007). Feeling the real world: Limbic response to music depends on related content. Cerebral Cortex, (17): 2828 - 2840 .

Enns, D. (2007). Identity and victimhood. Berghof Occasional Paper No. 28, Berghof Research centre for constructive conflict management: Berlin, 1 - 45 .

Erez, E., Kilchling, M. \& Wemmers, J. (2011). Therapeutic jurisprudence and victim participation in justice: International perspectives. Durham: Carolina Academic Press.

Erzar, T. (2018). Self-perceived victimhood and forgiveness in different generations of the right and left political group in Slovenia. Bogoslovni vestnik, 78(2): $461-471$.

Ferguson, C., \& Turvey, B. E. (2009). Victimology: A brief history with an introduction to forensic victimology, In: B. E. Turvey, \& W. A. Petherick (Eds.), Forensic Victimology: Examining Violent Crime, Victims in Investigative and Legal Contexts. San Diego: Elsevier Science, 1- 32.

Garlin, F. V., \& Owen, K. (2006). Setting the tone with the tune: A meta-analytic review of the effects of background music in retail settings. Journal of Business Research, (59): $755-764$.

Hanser, W. E. \& Mark, R. E. (2013). Music influences ratings of the affect of visual stimuli. Psychological Topics, 22(2): $305-324$.

Harris, A. P. (1991). The jurisprudence of victimhood. The Supreme Court Review, (1991): 77 - 102.

Hoeckner, B., Wyatt, E.W., Decety, J., \& Nusbaum, H. (2011). Film music influences how viewers relate to movie characters. Psychology of Aesthetics, Creativity and the Arts, (5): 146 - 153.

Hui, M. K., Dube, L., \& Chebat, J. C. (1997). The impact of music on consumers' reactions to waiting for services. Journal of Retailing, (73): 87 - 104.

Huron, D. (2003). Is music an evolutionary adaption? In: I. Peretz \& R. J. Zatorre (Eds.), The cognitive Neuroscience of Music. New York: Oxford University Press, 57 - 75.

Jacoby, T. A. (2015). A theory of victimhood: Politics, conflict and the construction of victim-based identity. Millennium, 43(2): 511 - 530.

Jolij, J. \& Meurs, M. (2011). Music alters visual perception. PLoS One, 6(4):1 - 5. 
Justin, P. N. \& Laukka, P. (2004). Expression, perception, and induction of musical emotions: A review and a questionnaire study of everyday listening. Journal of New Music Research, (33): $217-238$.

Kalinak, K. M. (1992). Setteling the score: Music and the classical Hollywood film. Madison: University of Winsconsin Press.

Kearns, J. N. \& Finchman, F. D. (2005). Victim and perpetrator accounts of interpersonal transgressions: Self-serving or relationship-serving biases? Personality and Social Psychology Bulletin, 31(3): 321 - 333 .

Koelsch, S., \& Siebel, W. A. (2005). Towards a neural basis of music perception. Trends in Cognitive Sciences, (9): $578-584$.

Magliano, J. P., Dijkstra, K. \& Zwaan R. A. (1996). Generating predictive inferences while viewing a movie. Discourse Processes, (22): 199 - 224.

Marshall, S. \& Cohen, A. J. (1988). Effects of musical soundtracks on attitudes to geometric figures. Music perception, (6): 95 - 112.

Menuhin, Y., \& Davis C. W. (1979). The music of man ( $1^{\text {st }}$ ed.). London: Methuen Co Ltd.

Mueller-Hirth, N. (2017). Temporalities of victimhood: Time in the study of post-conflict societies' Sociological Forum, 32(1): 186 - 206.

Noor, M., Vollhardt, J. R., Silvia, M. \& Nadler, A. (2017). The social psychology of collective victimhood: Special issue introduction. European Journal of Social Psychology, (47): 121 - 134.

North, A. C., Hargreaves, D. J. \& McKendrick, J. (1997). In-store music affects product choice. Nature, 390(6656): $101-204$.

Nwaozuzu, U. C., Abada, I. \& Aniago, E. (2020). Nigeria: delta oil exploration politics and the portrayal of brutal impact in Yerima's hard ground. Conflict Studies Quarterly. (32): 21-34

Oakes, S., \& North, A. C. (2008). Reviewing congruity effects in the service environment music-scape. International Journal of Service Industry Management, (19): 63 - 82.

Pauley, R. A. (1986). The emerging 'victim factor' in the supreme court's criminal jurisprudence: Should victims' interests ever prevent a court from overturning a conviction and ordering a retrial? Indiana Law Journal. 61(2): Article 2.

Pignatiello, M. F., Camp, C. J., \& Rasar, L. (1986). Musical mood induction: An alternative to the velten technique. Journal of Abnormal Psychology, (95): 295 - 297.

Raji, A. O. Y., \& Abejide, T. S. (2013). An assessment of environmental problems associated with oil pollution and gas flaring in the Niger Delta region Nigeria, 1960s-200o. Arabian Journal of Business and Management Review, 3(3): 48 - 62.

Saarikallio, S. (2010). Music as emotional self-regulation throughout adulthood. Psychology of Music, (39): $307-327$.

Sloboda, J. A., \& Juslin, P. N. (2001). Psychological perspectives on music and emotion, In: P. N. Juslin \& J. A. Sloboda (Eds.), Music and emotion theory and research. Oxford: Oxford University Press, $71-104$.

Sloboda, J. A., O'Neill, S. A., \& Ivaldi, A. (2001). Functions of music in everyday life: An exploratory study using the experience sampling method. Musicae Scientiae, (5): 9 - 32.

Tan, S. L., Spackman, M. P., \& Bezdek, M. A. (2007). Viewer's interpretations of film characters' emotions: Effects of film music before or after a character is shown. Music Perception, (25): 135 - 152.

United Nations' declaration of basic principles of justice for victims of crime and abuse of power adopted by General Assembly resolution 40/34 of 29 November 1985 pp. $1-3$

https://www.un.org/en/genocideprevention/documents/atrocitycrimes/Doc.29_declaration\%2ovictims \%2ocrime\%2oand\%2oabuse\%2oof\%2opower.pdf

Zadra, J. R., \& Clore, G. L. (2011). Emotion and perception: The role of affective information. Cognitive Science, (2): $676-685$.

Zander, M. F. (2006). Musical influences in advertising; how music modifies first impressions of product endorsers and brands. Psychology of Music, (34): 465-48o.

Film Cited

Blood and Oil. (2019). Curtis Graham. English, Vision Films \& Right-angle Productions. 